\title{
HUBUNGAN TINGKAT PENGETAHUAN GIZI DAN POLA MAKAN DENGAN KEJADIAN OBESITAS PADA SISWA SMK NEGERI 1 BIARO
}

\author{
Jufri Sineke ${ }^{1}$, Mirna Kawulusan ${ }^{2}$, Rudolf B. Purba dan Anita Dolang ${ }^{3}$ \\ Jurusan gizi Politeknik Kesehatan Kemenkes Manado \\ Email koteesponden: jufrisinekegz@gmail.com
}

\begin{abstract}
Obesity is a problem worldwide because of its increasing prevalence in adults and adolescents. Riskesdas results showed an increase in the prevalence of over nutrition in children aged 16-18 years, for the fat category from 1.4\% in 2010 to 7.3\% consisting of $5.7 \%$ fat and $1.6 \%$ obesity in 2013 . This study aims to determine the relationship between the level of nutritional knowledge and eating patterns with the incidence of obesity in students of Biaro 1 Vocational School. This research is an analytic observational descriptive study with cross sectional design, with a sample of 36 people who met the inclusion criteria. Data was collected through interviews using nutritional knowledge questionnaires and semi-FFQ forms to determine dietary patterns, and measurements of abdominal circumference for obesity data. Univariate analysis was performed descriptively and the bivariate analysis used was the correlation test with Kendall's tau-b with a value of $\alpha=0.05$. The results of this study showed that the level of nutritional knowledge of 36

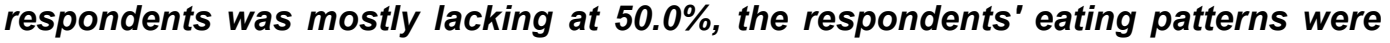
mostly not good at $80.6 \%$, and obesity status with an average abdominal circumference size of $80-85 \mathrm{~cm}$ was $55.7 \%$. Statistical test results show that there is a relationship between the level of nutritional knowledge and eating patterns with the incidence of obesity in students of State Vocational School 1 Biaro ( $p$ $<0.05)$.
\end{abstract}

Keywords: Nutrition Knowledge Level, Diet, Obesity Occurrence

\section{PENDAHULUAN}

Masalah obesitas merupakan masalah global yang sering terjadi pada masyarakat, baik masyarakat yang ada di negara maju maupun negara berkembang termasuk negara Indonesia. Obesitas menjadi masalah di seluruh dunia karena prevalensinya yang meningkat pada orang dewasa maupun remaja.

Lingkar perut merupakan metode yang digunakan untuk menentukan obesitas sentral. Pria dinyatakan mengalami obesitas sentral apabila lingkar perut menunjukkan lebih dari $90 \mathrm{~cm}$. Obesitas sentral merupakan keadaan kelebihan lemak yang terakumulasi di daerah abdomen (intra-abdominal fat). Obesitas berdampak buruk pada kesehatan. Risiko kematian meningkat pada obesitas, terutama obesitas yang disertai dengan peningkatan lemak intraabdominal (obesitas sentral).

Prevalensi overweight dan obesitas meningkat sangat tajam di kawasan Asia Pasifik. Sebagai contohpenduduk Korea Selatan yang memiliki status gizi overweight $20,5 \%$ dan obesitas $1,5 \%$. Di Thailand, $16 \%$ penduduk mengalamai overweight dan $4 \%$ mengalami obesitas. Di daerah perkotaan Cina, prevalensi overweight $12, \%$ pada laki- laki dan $14,4 \%$ pada perempuan, sedangkan di 
daerah pedesaan prevalensi overweight pada laki- laki dan perempuan masingmasing adalah 5,3\% dan 9,8\% (Iriyani dan Nurpudji, 2012).

World Health Organization (WHO) tahun 2011 memperkirakan di dunia ada sekitar 1,6 milyar remaja berumur 15 tahun kelebihan berat badan dan sebanyak 400 juta orang gemuk (obesitas) dan di perikirakan lebih dari 700 juta orang dewasa akan gemuk (obesitas) pada tahun 2015.(WHO, 2011). Berdasarkan data Riset Kesehatan Dasar (Riskesdas) 2013, didapatkan prevalensi obesitas pada anak berusia 5-12 tahun adalah 8,8\%, 13-15 tahun adalah 2,5\%, dan 16-18 tahun adalah $1,6 \%$ berdasarkan indeks massa tubuh menurut umur lebih dari Zscore menggunakan baku antropometri WHO 2007 untuk anak berumur 5-18 tahun. Hasil Riset Kesehatan Dasar (Riskesdas) menunjukkan terjadi peningkatan prevalensistatus gizi lebih pada anak usia 16-18 tahun yaitu untuk kategori gemuk dari 1,4\% pada tahun 2010 menjadi 7,3\% yang terdiri dari gemuk $5,7 \%$ dan obesitas $1,6 \%$ pada tahun 2013. (Balitbangkes, 2013).

Hasil Riset Kesehatan Dasar (Riskesdas) tahun 2013 di Sulawesi Utara dijelaskan bahwa status gizi anak remaja (13-15 tahun) berdasarkan IMT menurut Umur (IMT/U) yang memiliki gizi lebih adalah 2,7 \% sedangkan pada anak remaja usia 16-18 tahun, status gizi lebih 2,6\%. Prevalensi status gizi lebih di Kabupaten Siau Tagulandang Biaro pada remaja 13-15 tahun adalah 2,5\% dan remaja usia 16-18 tahun adalah 0,6\%. Prevalensi obesitas sentral usia $\geq 15$ tahun untuk provinsi Sulawesi Utara 37,4\% dan kota Manado 41,4\%. (Balitbangkes, 2013).

Obesitas pada remaja penting untuk diperhatikan karena remaja yang mengalami obesitas $80 \%$ berpeluang untuk mengalami obesitas pula pada saat dewasa. Selain itu, terjadi peningkatan remaja obesitas yang didiagnosis dengan kondisi penyakit yang biasadialami orang dewasa, seperti diabetes tipe 2 dan hipertensi. Remaja obesitas sepanjang hidupnya juga berisiko lebih tinggi untuk menderita sejumlah masalah kesehatan yang serius, seperti penyakit jantung, stroke, diabetes, asma, dan beberapa jenis kanker.Obesitas juga membawa konsekuensi psikologis dan sosial pada remaja, termasuk peningkatan risiko depresi karena lebih sering ditolak oleh rekan-rekan mereka serta digoda dan dikucilkan karena berat badan mereka. Obesitas terjadi karena berbagai faktor penyebab yang kompleks antara lain genetik, pola makan, aktivitas fisik dan faktor-faktor sosial budaya. Remaja obesitas menghabiskan waktu untuk aktivitas statis lebih lama daripada remaja non obesitas. (Puhl, 2007).

Pola makan yang merupakan pencetus terjadinya kegemukan dan obesitas adalah mengonsumsi makanan porsi besar (lebih dari kebutuhan), makanan tinggi energi, tinggi lemak, tinggi karbohidrat sederhana dan rendah serat. Sedangkan perilaku makan yang salah adalah tindakan memilih makanan berupa junk food, makanan dalam kemasan dan minuman ringan (soft drink) (Kemenkes RI, 2012). Kebiasaan makan yang buruk seperti rendahnya konsumsi buah-buahan dan sayur, rendahnya konsumsi susu rendah lemak dan tingginya konsumsi makanan dan minuman ringan serta kebiasaan tidak sarapan berpengaruh terhadap obesitas. Pola makan yang baik bagi orang Indonesia adalah pola makan yang sesuai dengan Pedoman Umum Gizi Seimbang (PUGS).

\section{METODE}

Jenis penelitian ini adalah Deskriptif observasional analik dengan rancangan penelitian cross sectiona studyl.Penelitian dilaksanakan pada Bulan November 
2018 di SMK Negeri 1 Biaro, Kepulauan Siau Tagulandang Biaro. Sampel penelitian merupakan siswa di SMK Negeri 1 Biaro yang memiliki berat badan obesitas yang berjumlah 36 sampel. Variabel bebas meliputi pengetahuan gizi, dan pola makan. Variabel terikat adalah kejadian obesitas. Uji statistik korelasi menggunakan Uji Kendall's tau-b.

\section{HASIL}

Berdasarkan tabel 1 dapat dilihat bahwa responden penelitian yang paling banyak adalah perempuan, dengan kelompok umur berada pada umur 14-17 tahun. Responden paling banyak adalah kelas 2 SMK dan jurusan yang paling banyak adalah jurusan perikanan.

Tabel 1. Distribusi Frekuensi Karakteristik Umum Subjek Penelitian

\begin{tabular}{|c|c|c|c|c|}
\hline \multirow{2}{*}{$\begin{array}{l}\text { Variabel } \\
\text { Jenis kelamin }\end{array}$} & \multirow[t]{2}{*}{$\mathbf{n}$} & \multicolumn{2}{|r|}{$\%$} & \\
\hline & & & \multirow[b]{2}{*}{36,1} & \\
\hline Laki-laki & \multicolumn{2}{|l|}{13} & & \\
\hline Perempuan & \multirow[t]{2}{*}{23} & & \multirow[t]{2}{*}{63,9} & \\
\hline \multicolumn{3}{|l|}{ Umur } & & \\
\hline 14 tahun & \multicolumn{2}{|l|}{3} & 8,3 & \\
\hline 15 tahun & \multicolumn{2}{|l|}{10} & 27,8 & \\
\hline 16 tahun & \multicolumn{2}{|l|}{17} & 47,2 & \\
\hline 17 tahun & \multirow[t]{2}{*}{6} & & \multirow[t]{2}{*}{16,7} & \\
\hline \multicolumn{3}{|l|}{ Kelas } & & \\
\hline Kelas 1 & \multicolumn{2}{|l|}{13} & 36,1 & \\
\hline Kelas 2 & \multicolumn{2}{|l|}{17} & 47,2 & \\
\hline Kelas 3 & \multirow{2}{*}{\multicolumn{2}{|c|}{6}} & \multirow[t]{2}{*}{16,7} & \\
\hline \multicolumn{2}{|l|}{ Jurusan } & & & \\
\hline Perikanan & \multicolumn{2}{|l|}{19} & \multicolumn{2}{|l|}{52,8} \\
\hline Pertanian & \multicolumn{2}{|l|}{17} & 47,2 & \\
\hline \multirow{2}{*}{ Lingkar perut } & \multicolumn{2}{|c|}{ Jenis Kelamin } & & \multirow{2}{*}{ Total } \\
\hline & \multicolumn{2}{|c|}{ Laki-laki } & puan & \\
\hline $80-85 \mathrm{~cm}$ & 3 & 18 & & 21 \\
\hline $86-90 \mathrm{~cm}$ & 2 & 4 & & 6 \\
\hline$>90 \mathrm{~cm}$ & 8 & 1 & & 9 \\
\hline Total & 13 & 23 & & 26 \\
\hline & Lingkar $\mathbf{P}$ & & & \\
\hline Tingkat Pengetahuan & $80-85 \mathrm{~cm}$ & $86-90 \mathrm{~cm}$ & $>90 \mathrm{~cm}$ & Total \\
\hline Baik & 3 & 0 & 0 & 3 \\
\hline Sedang & 13 & 3 & 3 & 19 \\
\hline Kurang & 6 & 2 & 6 & 14 \\
\hline Total & 22 & 5 & 9 & 36 \\
\hline
\end{tabular}

Tabel 1 di atas pun menunjukkan distribusi frekuensi lingkar perut siswa SMK Negeri 1 Biaro. Pada hasil analisis diketahui bahwa sebagian besar siswa yang mengalami obesitas berjenis kelamin perempuan dan memiliki lingkar perut paling banyak adalah $80-85 \mathrm{~cm}$. Menurut Pujiati (2010), laki-laki dan perempuan memiiki distribusi lemak yang berbeda-beda. Proporsi lemak pada laki-laki lebih banyak pada bagian atas tubuh, seperti bagian abdominal atau perut, sedangkan proporsi lemak pada wanita lebih banyak pada bagian bawah tubuh, seperti pinggang dan panggul. 
Demikian pula sebagian besar responden memiliki tingkat pengetahuan sedang dan kurang. Pengetahuan gizi diketahui merupakan salah satu faktor yang berpengaruh terhadap obesitas, semakin baik tingkat pengetahuan seseorang akan mempengaruhi pemilihan dan pola makan seseorang (Wardle dkk, 2000).

Berdasarkan hasil analisis menunjukkan bahwa sebagian besar siswa yang mengalami obesitas di SMK Negeri 1 Biaro memiliki pola makan tidak baik. Siswa dikategorikan memiliki pola makan tidak baik apabila mengkonsumsi jenis makanan penyebab obesitas dalam frekuensi sering. Menurut Masnar (2010), seseorang dengan pola makan tidak baik memiliki resiko lebih besar mengalami obesitas.

Data distribusi frekuensi pola makan responden adalah jenis makanan yang biasa dikonsumsi dalam kehidupan sehari-hari yang dapat menyebabkan obesitas jika dikonsumsi dalam jangka panjang. Adapun jenis makanan dikelompokkan berdasarkan makanan sumber karbohidrat, lauk hewani, lemak/minyak dan olahannya, minuman, dan makanan jajanan.

Hasil siswa SMK 1 Biaro yang obesitas mengkonsumsi makanan sumber karbohidrat paling banyak dalam frekuensi sering ( $>3 x$ seminggu), jenis makanan yang paling sering dikonsumsi adalah nasi putih dan ubi sebabagi makanan pokok, serta roti, biskuit, mie instan dan juga gula pasir. Makan sumber lauk hewani yang paling sering dikonsumsi oleh siswa obesitas di SMK Negeri 1 Biaro adalah jenis daging babi, daging ayam dan telur ayam. Sedangkan daging sapi dan daging kambing jarang dikonsumsi, hanya dikonsumsi jika ada acara-acara tertentu saja. Sedangkan, semua jenis lemak/minyak dan produk olahannya yaitu minyak kelapa, mentega, margarin, santan dikonsumsi dalam frekuensi sering oleh responden, hal ini karena produk lemak/minyak digunakan sebagai bahan tambahan dalam proses pengolahan makanan.

Hasil penelitian pun menunjukkan sebagian besar responden mengkonsumsi minuman bersoda, susu kental manis, dan ice cream dalam frekuensi sering. Jenis makanan ini diketahui adalah jenis makanan manis tinggi energy yang berkontribusi terhadap obesitas. Jenis makanan jajanan yang biasa dikonsumsi dalam frekuensi sering ( $>3 x$ seminggu) adalah donat, bakso, martabak, puding, batagor, kue basah, tahu isi, pisang goreng, dan cokelat. Menurut responden makanan ini sering dikonsumsi karena sering dijual dikantin sekolah, pedagang keliling, dan juga merupakan menu selingan dirumah . Jenis makanan adalah makanan tinggi energi, lemak, dan gula yang berkontribusi terhadap obesitas jika dikonsumsi dalam jangka panjang.

Hasil analisis menggunakan uji Korelasi dengan Kendall's tau- $b$ menyebutkan nilai $p$ value $=0,048(p<0,05)$, dan nilai korelasi $=0,272$ yang berarti terdapat hubungan yang cukup antara tingkat pengetahuan gizi dengan kejadian obesitas pada siswa di SMK Negeri 1 Biaro.

Tabel 2. Hubungan tingkat penegtahuan gizi terhadap kejadian obesitas

\begin{tabular}{lll}
\hline Variabel & Nilai Korelasi & $\boldsymbol{p}$ Value \\
\hline $\begin{array}{l}\text { Tingkat pengetahuan gizi } \\
\text { Kejadian obesitas }\end{array}$ & 0,272 & 0,048 \\
\hline
\end{tabular}

*Uji Kendall's tau-b

Setelah dilakukan analisis biaviat uji Korelasi dengan Kendall's tau-b diketahui bahwa nilai $p$ value $=0,000(p<0,05)$, dan nilai korelasi $=0,532$ yang berarti terdapat hubungan yang kuat antara pola makan dengan kejadian obesitas pada siswa di SMK Negeri 1 Biaro. 
Tabel 3. Hubungan pola makan terhadap kejadian obesitas

\begin{tabular}{lll}
\hline Variabel & Nilai Korelasi & $\boldsymbol{p}$ Value \\
\hline Pola makan & 0,532 & 0,000 \\
Kejadian obesitas & & \\
\hline${ }^{*}$ Uji Kendall's tau-b & &
\end{tabular}

\section{PEMBAHASAN}

1. Hubungan Tingkat Pengetahuan Gizi Terhadap Kejadian Obesitas

Menurut Baron (2004), sikap tumbuh diawali dari pengetahuan yang dipersepsikan sebagai suatu hal yang baik maupun yang tidak baik, kemudian diinternalisasikan ke dalam dirinya. Hal ini dapat diartikan bahwa sikap yang baik dan kurang terbentuk dari komponen pengetahuan dan hal ini akan mempengaruhi perilaku seseorang dalam hal ini adalah pemilihan makanan yang seimbang.

Hal ini berkaitan dengan teori yang mengatakan bahwa tingkat pengetahuan gizi seseorang berpengaruh terhadap sikap dan perilaku dalam memilih makanan yang menentukan mudah tidaknya seseorang memahami manfaat kandungan gizi dari makanan yang dikonsumsi (Sediaoetama, 2000). Selanjutnya, Sediaoetama (2000) berpendapat bahwa kesalahan dalam memilih makanan dan kurang cukupnya pengetahuan tentang gizi akan mengakibatkan timbulnya masalah gizi yang akhirnya mempengaruhi status gizi. Status gizi yang baik hanya dapat tercapai dengan pola makan yang baik, yaitu pola makan yang didasarkan atas prinsip menu seimbang, alami, dan sehat.

Hasil penelitian ini menunjukkan bahwa terdapat hubungan yang sangat kuat antara tingkat pengetahuan gizi dengan kejadian obesitas pada siswa SMK Negeri 1 Biaro dimana nilai $p=0,042(p<0,05)$. Hasil ini sesuai dengan penelitian yang dilakukan Jasminah dan Mahmudiono (2018), yang menyebutkan bahwa terdapat hubungan antara tingkat pengetahuan gizi dengan kejadian obesitas. Hasil penelitian Andriasti dan Saraswati (2018) juga menyebutkan bahwa tingkat pengetahuan gizi berpengaruh terhadap kejadian obesitas pada remaja.

Menurut teori yang ada, dijelaskan bahwa obesitas merupakan suatu keadaan yang ditandai oleh penimbunan lemak tubuh secara berlebihan Penimbunan lemak terjadi karena ketidakseimbangan asupan energi yang masuk dengan asupan energi yang keluar. Dimana pada usia remaja membutuhkan asupan gizi yang berlebih untuk proses pertumbuhan dan perkembangan, namun karena kurangnya pengetahuan akan asupan gizi yang optimal, mengakibatkan banyak remaja mengkonsumsi makanan yang berlebihan dan tidak sesuai dengan kebutuhannya. Pengetahuan gizi mengajarkan bagaimana komposisi dan kualitas makanan yang masuk seseuai keperluan kita.

Pola konsumsi makanan adalah susunan jumlah dan jenis beberapa makanan yang dikonsumsi seseorang atau kelompok pada waktu tertentu untuk pengaturan makan. Pola konsumsi makan disebut juga dengan kebiasaan makan. Pola konsumsi makanan yang baik berpengaruh positif terhadap kesehatan tubuh seseorang seperti mencegah atau membantu menyembuhkan penyakit. Begitu juga sebaliknya, jika pola konsumsi makanan yang kurang baik akan mempengaruhi status gizi anak. Pola makan dapat diukur secara kuantitatif 
dengan melihat jenis makanan, takaran berat, porsi, dan frekuensi, sedangkan secara kualitatif dapat dilihat melalui jenis dan komposisi makanan saja. Kebiasaan makan yang tidak baik seperti kelebihan makan makanan jajanan yang tinggi lemak, tinggi gula, dan tinggi kalori dapat menyebabkan overweight atau obesitas pada anakdan remaja (Wansink, et al., 2013).

Hasil penelitian ini adalah untuk melihat pola makan yaitu frekuensi dan jenis bahan makanan memicu obesitas. Hasil analisis data pada penelitian ini membuktikan adanya hubungan kuat antara pola makan terhadap kejadian obesitas pada siswa SMK Negeri 1 Biaro dengan nilai $p=0,00(p<0,05)$. Hal ini terjadi karena sebagian besar siswa yang mengalami obesitas mengkonsumsi makanan yang dapat memicu obesitas dalam frekuensi sering ( $>3 x$ seminggu). Makanan tinggi energi, tinggi lemak, dan gula menjadi penyebab utama obesitas jika sering dikonsumsi dalam jangka waktu panjang. Hasil ini sesuai dengan penelitian Evan dkk (2017) bahwa pola makan berhubungan erat dengan kejadian obesitas pada remaja. Putra (2017, menjelaskan bahwa responden dengan pola makan tidak baik/berlebih mempunyai kecendurangan 2,6 kali lebih besar terjadinya overweight atau obesitas daripada responden dengan pola makan baik/cukup.

Hasil penelitan Mokolensang dkk (2016), menyebutkan bahwa frekuensi makanan sumber lemak dan karbohidrat yang paling banyak dikonsumsi remaja adalah nasi, mie instan, minuman bersoda, telur ayam, dan daging ayam, hasil penelitian ini juga menjelaskan asupan energi, karbohidrat dan lemak yang paling berpengaruh terhadap kejadian obesitas pada remaja.

Menurut hasil penelitian Nisak dan Mahmudiono (2017), anak dan remaja yang mengkonsumsi makanan sumber karbohidrat, tinggi gula, makanan jajanan seperti cokelat, susu kental manis, bakso, gorengan, mie instan, kue basah, biskuit dalam frekuensi sering berhubungan erat dengan terjadinya obesitas. Lebih lanjut Nisak dan Mahmudiono (2017), juga menjelaskan bahwa ada hubungan pola konsumsi makanan gorengan dalam frekuensi harian dan mingguan dengan kejadian overweight/obesitas pada anak sekolah. Hasil analisis frekuensi pola makan jenis gorengan seperti tahu isi dan pisang pada siswa di SMK Negeri 1 Biaro di konsumsi dalam frekuensi sering ( $>3 x$ seminggu). Hasil penelitian lain juga menyebutkan bahwa makan makanan digoreng (gorengan) ada hubungannya dengan penambahan lingkar pinggang (Rouhani, et al., 2012).

Lingkungan sekolah merupakan salah satu faktor yang mempengaruhi asupan makan anak yang diperoleh dari konsumsi makanan jajanan di sekolah (Martin, 2017). Konsumsi makanan jajanan yang berlebihan juga dapat menyebabkan peningkatan berat badan apabila pilihan jajanan berupa makanan yang tinggi kalori, lemak, gula, dan rendah zat gizi (Steiner, et al., 2012). Makanan jajanan berefek kepada kejadian overweight/obesitas disebabkan oleh kandungan gizinya (Habsiyah, 2015). Contohnya yaitu makanan jajanan gorengan yang mengandung banyak lemak. Frekuensi kebiasaan makan jajan yang berlemak dalam harian akan berakibat terjadinya penumpukan lemak dalam tubuh dan beresiko untuk menaikkan berat badan, yang nantinya akan berakibat pada kejadian overweight/obesitas (Qi, Qibin, et al., 2014).

\section{KESIMPULAN}

Tingkat pengetahuan responden sebagian besar masih kurang $(50,0 \%)$, pola makan sebagian besar dengan kategori tidak baik $(80,6 \%)$, status obesitas 
dengan lingkar perut $80-85 \mathrm{~cm}$ sebesar $55,7 \%$. Terdapat hubungan antara tingkat pengetahuan gizi dengan kejadian obesitas, dan terdapat hubungan antara tingkat pengetahuan gizi dengan kejadian obesitas, dan terdapat hubungan antara pola makan dengan kejadian obesitas.Unit Kesehatan Sekolah dapat dapat melakukan pemantauan berat badan, tinggi badan, dan lingkar perut untuk memantau status gizi siswa. Puskesmas maupun dinas kesehatan setempat bekerja sama dengan sekolah untuk melakukan penyuluhan dan konsultasi gizi mengenai pola makan dan obesitas pada siswa.

\section{DAFTAR PUSTAKA}

Arisman, 2010. Hubungan Tingkat Pengetahuan Gizi Dengan Kejadian Obesitas Pada Remaja Putri Usia 17-19 Tahun .Universitas Hasanudin Makasar.

Anrasili J, Saraswati M.R,2018. Hubungan Antara Tingkat Pengetahuan Gizi Terhadap Terjadinya Obesitas Pada Anak SMA Di Denpasar. E-JURNAL MEDIKA,Vol.7 No 7,Juli,2018

Badan Penelitian dan Pengembangan Kesehatan Kemenkes (Balitbangkes). 2013. Laporan Hasil Riset Kesehatan Dasar 2013. Departemen Kesehatan Republik Indonesia, Jakarta.

Baron, R. A., Byrne, D. E. 2004. Social Psychology. Pearson. USA

Bowman, Barbara A, and Robert M. Russel, 200). Present Knowledge in Nutrion eight edition. International Life Sciences Institute: Washington

Emilia, E., 2008. Pengembangan Alat Ukur Pengetahuan, Sikap dan Praktek pada Gizi Remaja. http://repository.ipb.ac.id/

Evan, Wiyono J, Candrawati E, 2017. Hubungan antara pola makan dengan kejadian obesitas pada mahasiswa di universitas tribhuwana tunggadewi malang. Nursing News Volume 2, Nomor 3, 2017

Freitag, H. (2010). Bebas Obesitas Tanpa Diet Menyiksa. Yogyakarta : Media pressindo.

Habsiyah, Y. 2015. Perilaku Konsumsi Makanan Jajanan Dengan Berat Badan Anak Prasekolah Di TK Tarbiyatush Shibyan Desa Gayaman Mojoanyar Mojokerto.http://repository.poltekkesmajapahit.ac.id/index.php/PUBKEB/article/viewFile/464/378

Hanson NI, Neumark-Sztainer D, Eisenberg ME, et.al, 2005. Associations between parental report of the home food environment and adolescent Hasdianah H.R. 2014. Gizi Pemanfaatan Gizi, Diet dan Obesitas. Yogyakarta : Nuha Medika.

Indriati E, 2012. Antropometri Untuk Kedokteran, Keperawatan, Gizi, dan Olahraga. Yogyakarta :Citra Aji Parama.

Khomsan, Ali. (2004). Pangan dan Gizi Untuk Kesehatan. Jakarta : Raja Grafindo Persada.

Martin, L. 2017. Evidence for environmental interventions to prevent childhood overweight and obesity within schools. NHS Health Scotland.

Masnar, 2010. Hubungan Faktor Determinan Gaya Hidup Terhadap Obesitas Sentral Pada Berbagai Status Ekonomi di Sulawesi (Analisis Data Riskesdas 2007). Skripsi. Fakultas Kesehatan Masyarakat. Universitas Hassanudin Makasar.

Mokolensang OG, Manampiring A, Fatimawati, 2016. Hubungan Pola Makan dan Obesitas Pada Remaja di Kota Bitung. Jurnal e-Biomedik (eBm), Volume 4, Nomor 1, Januari-Juni 2016 
Nisak AJ, Mahmudiono T, 2017. Pola Konsumsi Makanan Jajanan Di Sekolah Dapat meningkatkan resiko overweight/obesitas pada anak 9studi di SD Negeri Ploso I-172 Kecamatan Tambaksari Surabaya Tahun 2017). Jurnal Berkala Epidemiologi, volume 5 Nomor 3, September 2017, hlm. 311-324

Notoatmodjo, S. 2003. Pendidikan dan Perilaku Kesehatan. PT. Rineka Cipta. Jakarta Jakarta

2007. Promosi Kesehatan dan IImu Perilaku. PT Rineka Cipta

O'Dea JA \& Wilson R, 2006. Socio-cognitive and nutritional factors associated with body mass index in children and adolescents: possibilities for childhood obesity prevention. Health Educ Res.

Puhl RM LJS. obesity, and the health of the nation's children. Psychol Bull. 2007.

Pujiati, 2010. Prevalensi dan Faktor Resiko Obesitas Sentral Pada Penduduk Dewasa Kota dan Kabupaten Indonesia Tahun 2007. Program Pascasarjana, Universitas Indonesia, Jakarta.

Putra W.N, 2017. Hubungan pola makan, aktivitas fisik dan aktivitas sedentari dengan overweight di sma negeri 5 surabaya. Jurnal Berkala Epidemiologi, Volume 5 Nomor 3, September 2017, hlm. 298-310

Qi, Q., Audrey, Y C., Jae, H K., Jinyan, H., Lynda, M R., Majken, K J. 2014. Fried food consumption, genetic risk, and body mass index: gene-diet interaction analysis in three US cohort studies. BMJ. http://www.bmj.com/content/bmj/348/bmj.g

Rouhani, M H., Maryam, M., Nasrin, O., Ahmad, E., Leila, A. 2012. Fast Food Consumption, Quality of Diet, and Obesity among Isfahanian Adolescent Girls. Journal of Obesity Volume 2012.

Sebayang A, 2012. Gambaran pola makanan mahasiswa di universitas Indonesia. Skripsi. Universitas Indonesia

Sediaoetama, A. D. 2000. IImu Gizi Untuk Mahasiswa dan Profesi Jilid I. Dian Rakyat. Jakarta.

Soegondo S. Obesitas. Dalam : Sudoyo. AW, Setiyohadi. Buku Ajar IImu Penyakit Dalam. Jakarta: Pusat penerbit ilmu penyakit dalam FKUI. 2006: 1919-25.

Soetjiningsih, 2011. Tumbuh Kembang Anak. Jakarta : EGC

Sulistyoningsih H, 2010. GIZI untuk Kesehatan Ibu dan Anak, Graha IImu, Yogyakarta

Steiner-Asiedu M., Jantuah, J E., Anderson, A K. 2012. The Snacking Habits in Junior High School Students: The Nutritional Implication-a Short Report. Asian J Med Sci., 4(1):42-6

Sugiyono. 2008. Metode Penelitian Kuantitatif, Kualitatif. Alfabeta. Bandung

Wansink, B., Mitsuru, S., Adam, B. 2013. Association of Nutrient-Dense Snack Combinations With Calories and Vegetable Intake. Pediatrics, 131 (1): pp. $22-29$ 